\title{
An Examination of 5th Grade Mathematics Curriculum in Terms of 21st Century Skills \\ Ömer Faruk VURAL ${ }^{1}$, Selma VURAL ${ }^{2}$
}

\begin{tabular}{l} 
ARTICLE INFO \\
\hline Article History: \\
Received 05.05 .2020 \\
Received in revised form \\
05.12 .2020 \\
Accepted \\
Available online 01.04 .2021
\end{tabular}

INTRODUCTION

It is seen that due to the social, economic, political and technological developments in the 21st century, the required professional qualifications have started to change and their future expectations have started to differ. Various changes are expected in education systems in line with these needs and expectations (Schleicher, 2012). In today's world, it is more important to understand and use information, to distinguish between important and unimportant information and to associate information with daily life rather than transferring information to students. Education professionals stated that schools should focus on life skills rather than technical skills so that individuals can adapt to change. In this direction, various institutions have tried to define the skills that individuals should have in the 21st century and named these skills as 21st century skills. 21st century skills are one of the important issues that are emphasized by those who direct education today (Ananiadou and Claro, 2009). The reason for this is that we need to determine what skills and knowledge we want the people we want to train 20 years later to have. Although 21st century skills are defined differently by different institutions, we can say that the main skills mentioned are generally the same.

Rotherham and Willingham (2009) emphasized that the skills defined as the 21st century are not new skills, and these skills have been discussed before. As a matter of fact, while creativity was a skill required to design a new agricultural tool a century ago, it is still popular today as a skill required to design an electronic device. In fact, when looking at the historical process, the skills needed in the 21st century are not

\footnotetext{
${ }^{1}$ Corresponding e-mail: ${ }^{1}$ Sakarya University, omervural@sakarya.edu.tr, orcid.org/0000-0002-1520-3762 ${ }^{2}$ Gaziantep University ,selma5454@gmail.com, orcid.org/0000-0003-2053-132X

Note: Preliminary results of this study were presented at the 5th International Education and Social Sciences Conference held in istanbul, 27-29 June 2019
}

\begin{abstract}
In today's world, schools should emphasize on life skills rather than technical skills, so that individuals can adapt to changes. In this respect, various institutions tried to define the skills that individuals should have in the 21st century, called as 21 st century skills. 21st century skills are one of the most
important issues in education. The reason for this is that we need to determine nowadays what skills and knowledge the generations will have after 20 years. In mathematics courses taught in Turkey are covered in terms of acquiring 21st century skills through the acquisitions and explanations determined by the was used in this study. At the end of the study, there was no data found regarding to "learning to learn", "taking initiative and entrepreneurship", mathematics curriculum. 5th grade mathematics lesson objectives remained missing to take initiative and develop entrepreneurship skills. The findings showed that "problem solving", "critical thinking", "creativity", "ICT literacy", "social and cultural skills and citizenship" and "cooperation" skills were found but inadequate in the objectives of the fifth grade mathematics curriculum. terms of gaining 21 st century skills. In general, the fifth grade mathematics (C) IJERE. All rights reserved

Keywords:

Mathematics Curriculum, Secondary School Mathematics Curriculum, Teachers' Opinions.
\end{abstract}


new skills. Different segments of the society needed these skills in previous centuries (Ekici, Abide, Canbolat and Öztürk, 2017). Although these required skills are named in the same way, there have been various differences in the scope, meaning and application of the skill. Today, these skills are especially highlighted by educators and employers. Silva (2009) stated that 21st century skills are not new, but they are becoming more important today. In addition, these skills used to be skills belonging to certain occupational groups, but today they have become a skill that everyone should have.

21st century skills primarily include providing students with the knowledge of basic subjects and gaining some skills on this basic field knowledge. In short, we can say that the achievements come from the blending of knowledge and skills (Dede, 2010). In Voogt and Roblin 's (2010) study, which defines 21st century skills, eight different 21st century skills are mentioned in different frameworks. These are P21, En Gauge, ATCS, NETS/ISTE, EU, OECD, UNESCO and NAEP frameworks. Different institutions have defined 21st century skills differently depending on the profile of people they need. Six of these frameworks, except for UNESCO and NAEP, are summarized in Table 1 (Voogt and Roblin, 2010).

Table 1. Classification of 21st Century Skills in Different Frameworks

\begin{tabular}{|c|c|c|c|c|c|}
\hline $\begin{array}{l}\text { P21 (Partnership for } \\
\text { 21st Century Skills) }\end{array}$ & $\begin{array}{l}\text { NCREL En Gauge } \\
\text { (North Central Regional } \\
\text { Educational Laboratory) }\end{array}$ & $\begin{array}{l}\text { ATCS (Assessment } \\
\text { and Teaching of } 21 \\
\text { Century Skills) }\end{array}$ & $\begin{array}{l}\text { NETS / ISTE (National } \\
\text { Educational Technology } \\
\text { Standards) }\end{array}$ & EU (European Union) & $\begin{array}{l}\text { OECD (Organization } \\
\text { for Economic } \\
\text { Cooperation and } \\
\text { Development) }\end{array}$ \\
\hline $\begin{array}{l}\text { Learning and } \\
\text { innovation skills } \\
\text { 1. Critical thinking } \\
\text { 2. Problem solving } \\
\text { 3. Creativity and } \\
\text { innovation } \\
\text { 4. Communication } \\
\text { 5. Collaboration }\end{array}$ & $\begin{array}{l}\text { Inventive thinking } \\
\text { 1. Adaptability, } \\
\text { managing complexity } \\
\text { and self-direction; } \\
\text { 2. Curiosity, creativity } \\
\text { and risk taking; } \\
\text { 3. Higher order thinking } \\
\text { and sound reasoning. } \\
\text { Effective } \\
\text { communication } \\
\text { 1. Teaming, } \\
\text { collaboration and } \\
\text { interpersonal skills; } \\
\text { 2. Personal, social and } \\
\text { civic responsibility; } \\
\text { 3. Interactive } \\
\text { communication }\end{array}$ & $\begin{array}{l}\text { Ways of thinking } \\
\text { 1. Creativity and } \\
\text { innovation; } \\
\text { 2. Critical thinking, } \\
\text { problem solving, } \\
\text { decision making; } \\
\text { 3. Leadership to learn, } \\
\text { metacognition } \\
\text { Ways of working } \\
\text { 1. Communication } \\
\text { 2. Collaboration } \\
\text { (teamwork) }\end{array}$ & $\begin{array}{l}\text { Creativity and innovation } \\
\text { Creative thinking, construct } \\
\text { knowledge, and develop } \\
\text { products and processes } \\
\text { using technology } \\
\text { Critical thinking, problem } \\
\text { solving and decision } \\
\text { making } \\
\text { Communication and } \\
\text { collaboration } \\
\text { Students use digital media } \\
\text { and environments to } \\
\text { communicate and work } \\
\text { collaboratively }\end{array}$ & $\begin{array}{l}\text { Communication } \\
\text { 1. Communication in } \\
\text { the mother tongue; } \\
\text { 2. Communication in a } \\
\text { foreign languages }\end{array}$ & $\begin{array}{l}\text { Interacting in } \\
\text { heterogeneous groups } \\
\text { 1. Relate well to others; } \\
\text { 2. Cooperate, work in } \\
\text { teams; } \\
\text { 3. Manage and resolve } \\
\text { conflicts. }\end{array}$ \\
\hline $\begin{array}{l}\text { Life and career skills } \\
\text { 1.Flexibility and } \\
\text { adaptability } \\
\text { 2. Initiative and self- } \\
\text { direction } \\
\text { 3. Social and cross- } \\
\text { cultural skills } \\
\text { 4. Productivity and } \\
\text { accountability } \\
\text { 5.Leadership and } \\
\text { responsibility }\end{array}$ & $\begin{array}{l}\text { High productivity } \\
\text { 1. Prioritizing, planning } \\
\text { and managing for } \\
\text { results; } \\
\text { 2. Effective use of real } \\
\text { world tools; } \\
\text { 3. Ability to produce } \\
\text { relevant, high quality } \\
\text { products. }\end{array}$ & $\begin{array}{l}\text { Living in the world } \\
\text { 1. Citizenship - local } \\
\text { and global; } \\
\text { 2. Life and career; } \\
\text { 3. Personal and social } \\
\text { responsibility } \\
\text { (including cultural } \\
\text { awareness and } \\
\text { competence) }\end{array}$ & $\begin{array}{l}\text { Digital citizenship } \\
\text { Understanding human, } \\
\text { cultural and social issues } \\
\text { related to technology }\end{array}$ & $\begin{array}{l}\text { Cultural awareness } \\
\text { and expression } \\
\text { Social and civic } \\
\text { competences } \\
\text { Sense of initiative and } \\
\text { entrepreneurship }\end{array}$ & $\begin{array}{l}\text { Acting autonomously } \\
\text { 1. Act within the big } \\
\text { picture; } \\
\text { 2. Form and conduct } \\
\text { life plans and personal } \\
\text { projects; } \\
\text { 3. Defend and assert } \\
\text { rights, interests and } \\
\text { needs. }\end{array}$ \\
\hline $\begin{array}{l}\text { Information, media } \\
\text { and technology skills } \\
\text { 1. Information literacy } \\
\text { 2. Media literacy } \\
\text { 3. Technology literacy }\end{array}$ & $\begin{array}{l}\text { Digital age literacy } \\
\text { 1. Basic, scientific, } \\
\text { economic and } \\
\text { technology literacies; } \\
\text { 2. Visual and } \\
\text { information literacies; } \\
\text { 3. Multicultural literacy } \\
\text { and global awareness. }\end{array}$ & $\begin{array}{l}\text { Tools for working } \\
\text { 1. Information literacy } \\
\text { 2. Information, } \\
\text { communication } \\
\text { technology literacy }\end{array}$ & $\begin{array}{l}\text { Technology operations and } \\
\text { concepts } \\
\text { Sound understanding of } \\
\text { technology concepts, } \\
\text { systems and operations. } \\
\text { Research and information } \\
\text { fluency } \\
\text { Apply digital tools to gather, } \\
\text { evaluate and use } \\
\text { information. }\end{array}$ & Digital competence & $\begin{array}{l}\text { Using technology tools } \\
\text { interactively } \\
\text { 1. Use language, } \\
\text { symbols and text } \\
\text { interactively; } \\
\text { 2. Use knowledge and } \\
\text { information } \\
\text { interactively; } \\
\text { 3. Use technology } \\
\text { interactively }\end{array}$ \\
\hline
\end{tabular}

The reason why Voogt and Roblin (2010) did not include UNESCO and NAEP in the table above is that 21st century skills were not defined in both. In addition, UNESCO was influenced by P21 when defining skills, while NAEP focused on technology literacy-related skills. Voogt and Roblin $(2010,2012)$ mentioned the most common 21st century skills after classifying 21st century skills in their study are "collaboration, communication, ICT literacy, social and cultural skills and citizenship, creativity, critical thinking, problem solving, productivity" skills. It is also useful to know that in the study of Voogt and Roblin, "risk taking, conflict management and resolution, entrepreneurship, interdisciplinary themes, core issues" is only within the framework of 21st century skills. 
21st century skills are included in the education programs of countries such as Austria, Belgium, Finland, Ireland, Italy, Canada, Norway and New Zealand (OECD, 2009). In Turkey, the primary education program implemented in 2004, 21st century skills students acquire skills attempted to Turkey Qualifications Framework (TQF) has identified eight key competences. These competencies are referred to as "communication in the mother tongue, communication in foreign languages, mathematics and science / technology core competencies, digital competence, learning to learn, social and civic competencies, taking initiative and entrepreneurship, cultural awareness and expression competencies" (MEB, 2018). These competencies are described in Table 2.

Table 2. Skills Competencies Defined Within the Framework of Turkey

\section{Turkey Qualifications Framework

Communication in mother
tongue \\ Communication in foreign languages}

Mathematical and science / technology core competencies

\section{Digital competence}

\section{Learning to learn}

Social and civic competencies

Taking initiative and entrepreneurship

Cultural awareness and expression competencies

\section{Definition}

Expressing and interpreting concepts, thoughts, opinions, feelings and facts in native language both verbally and in writing

Expressing and interpreting emotions, thoughts, concepts, facts and opinions in foreign languages both verbally and in writing

Developing and applying mathematical thinking style to solve a series of problems encountered in daily life.

Using computers for accessing and evaluating, storing, producing, presenting and exchanging information and participating in common networks via the internet

It is an individual's awareness of the possibilities for learning and coping with difficulties for a successful learning action.

It will enable individuals to participate effectively and constructively in differentiating society and working life; It covers all forms of behavior that enable it to be equipped with features to resolve conflicts when necessary.

Includes creativity, innovation, and risk taking, as well as the ability to plan and manage projects to achieve goals.

Creative expression of views, experiences and emotions using a variety of mass media such as music, performing arts, literature and visual arts

In the new education programs prepared by the Ministry of National Education, while defining the individuals of today, stated that they should have "Producing knowledge, using functionally in life, problem solving, critical thinking, entrepreneurial, decisive, having communication skills, empathy, contributing to society and culture, etc. qualifications"(MOE, 2018, p.4). Also students completing secondary school in the new curriculum is expected to have gained basic skills and competencies in Turkey Qualifications Framework (TQF). It is emphasized that especially field knowledge is important in 21st century skills. It is stated that 21st century skills should be built on field knowledge, so individuals should know the basic subjects well (Framework for 21st Century Learning, 2019). While teaching the content of the mathematics lesson, which is one of the basic field courses, students should be equipped with 21st century skills in the course activities and during the course process. Since mathematics lesson is an abstract field, students generally have difficulties. But since it forms the basis of other numerical courses, students must necessarily learn well. The Ministry of National Education has started development, renewal and updating of education programs in line with the changing education philosophy since 2005. In this direction, the primary school curriculum was updated first. Renovations and updates were continued, and with the works that gained speed in 2015, a comprehensive renewal was made in 51 areas by adding different dimensions since the 2016-2017 academic year. According to the renewed programs, education was first implemented in the 1st, 5th and 9th grades as of the 2017-2018 academic year. Starting from the 2018-2019 academic year, other education programs will be implemented in all classes.

The content of the 5th grade is especially important in terms of forming the basic framework of the subjects to be taught in secondary school and teaching the general main subjects to be taught in the following years (Porter, 1989). It is expected to learn to read and write natural numbers in 5th grade 
mathematics lesson about numbers and operations, understanding four operations in natural numbers, whole and compound fractions, conversion in fractions, ordering fractional numbers from small to large, adding and subtracting fractions, decimal representation of fractions, percentage concept and percentage representation of fractional numbers, associating the concept of percent with fraction and decimal notation (İzci and Göktaş, 2014). It is aimed to draw the surface opening and calculate its area, describe, show and draw basic concepts such as line, line segment and ray in geometry and measurement, name polygons and recognize basic elements, recognize units of length measurement, convert and calculate perimeter of polygons, calculate area of rectangle, recognize rectangular prism, know basic properties. The students are expected to create research questions that require data collection on data processing, and to present and interpret the data appropriate to these questions in the table, frequency table and column chart.

Goldsmith and Mark (1999) determined the features that mathematics curriculum should have in their study. These features are; allow the use of educational technologies in the teaching process, support individual work as well as collaborative learning, be suitable for mathematical thinking and discussion, and be oriented towards understanding and solving problems correctly. Again, Checkley's (2006) research on the fundamentals of mathematics curriculum and the features of an effective program reached the following results: students' mathematical thinking, problem solving and communication skills should be developed; students' individual differences and learning styles should be taken into account in the course process; the developments of the students should be evaluated and monitored continuously during the course. Peretz (2006) found in the research that concepts are learned in a more permanent and connected way in curricula prepared using a constructivist approach. Moreover, it improves students' reasoning skills, facilitates the learning of mathematics by concretizing the concepts, and gives the teacher the opportunity to make changes in the implementation of the program.

Considering the studies on the secondary school 5th grade mathematics lesson program; Berkant and Incecik (2018) concluded that mathematics teachers who teach in the fifth grade of secondary school are generally "undecided" regarding the fifth grade curriculum of the secondary school mathematics lesson. Bolat Soycan (2006) stated that according to the study, the secondary school fifth grade mathematics program based on the constructivist approach is handled appropriately in the lessons according to the constructivist approach. In the study conducted by İzci and Göktaş (2014) about the fifth grade mathematics curriculum, they reported that mathematics teachers' opinions about the program outcomes were generally positive, and their views on the content, learning-teaching process and evaluation process of the program included both positive and negative views. In the study of Taşçı (2004), it was revealed that teachers found the changes insufficient made in the mathematics program and more changes should be made in the program.

In this study, it was tried to reveal which skills the mathematics course outcomes taught in 5th grades, which is the first stage of secondary school, cover within the framework of the competencies and explanations determined by the Ministry of Education and the most common 21st century skills determined by Voogt and Roblin (2010) (critical thinking, creativity, problem solving, communication, social and cultural skills and citizenship, collaboration, productivity, ICT literacy). Also, one of the eight competences defined in the Turkey Qualifications Framework 'math and science skills / core competencies in technology, "analyzed the dimensions.

\section{METHOD}

In this study, qualitative research method was used, document analysis was preferred as a research design. Data source was "2018 Mathematics Program" and descriptive analysis was preferred for data analysis. Qualitative research is defined as a study in which qualitative data collection methods such as observation, interview and document analysis are used, and a qualitative process is followed to reveal perceptions and events in a realistic and holistic manner in the natural environment (Ylldırım \& Şimşek, 2011). In the research, fifth grade mathematics teaching program outcomes prepared by the Board of Education and Discipline in 2018 with the permission of the Ministry of National Education were used as data sources. The data was published electronically by the Ministry of National Education. Document analysis was used as a data collection method. In case study, it is aimed to describe the subject comprehensively (Bloor \& Wood, 2006). 
Document analysis method was used as data collection method in the research. First of all, 5th grade mathematics curriculum published 2018 was obtained from the official website of the Board of Education and Discipline affiliated to the Ministry of National Education. The objectives of this teaching program were compared with the objectives of the textbook and its accuracy was checked. Then, the data in the book was analyzed in line with the purpose of the research.

The data obtained from the fifth grade mathematics curriculum were analyzed using descriptive analysis and descriptive statistical methods. Data obtained in descriptive analysis are summarized and interpreted according to previously determined themes (Yıldırım \& Şimşek, 2011). The themes in this study are "collaboration, communication, ICT literacy, social and cultural skills, and citizenship, creativity, critical thinking, problem solving, productivity" skills, which are the common skills that Voogt and Roblin (2012) revealed in their 21st century skills comparison. In addition, the Ministry of National Education put into practice in 2005 defined for 21st century skills were used as another analysis theme in the competencies. These competencies are eight as "communication in mother tongue, communication in foreign languages, mathematics and science/technology core competencies, digital competence, learning to learn, social and civic competencies, taking initiative and entrepreneurship, cultural awareness and expression competencies". It has not been examined whether the competencies of " communication in mother tongue" and " communication in foreign languages " are reflected in the achievements of the mathematics lesson. Since "mathematics and science/technology core competencies" is directly related to the mathematics curriculum as a skill, the sub-dimensions of this competence were examined whether their skills are reflected in the fifth grade mathematics curriculum.

The sub-dimensions of this competence are

- Solving problems encountered in daily life with mathematical thinking style,

- Logical and spatial thinking,

- Developing skills in using mathematical modes (formulas, models, constructs, graphs and tables)

- Scientific research skills,

- Meeting their requests and needs with information and methodology applications.

While analyzing the data, the frequencies of the categories created by the researcher were calculated and displayed on the graph. Later, these frequencies were compared and interpreted and the data were analyzed.

In addition, two different researchers coded and compared the data independently for reliability. In comparison, no statistical process was applied, a general comparison was made, and no inconsistency was found in the coding of the researchers in general.

\section{FINDINGS}

There are five learning areas in the secondary school mathematics curriculum: numbers and operations, algebra, geometry and measurement, data processing and probability. Of these, the area of learning algebra is taught in the sixth grade and beyond. The subject of probability is the subject of the eighth grade. In the fifth grade, numbers and operations, geometry and measurement and data processing are covered. There are 56 objectives in these three subject areas in the fifth grade mathematics curriculum. Table 3 shows the subject areas and the objectives distribution table. 
Table 3. Fifth Grade Mathematics Curriculum Objectives Distribution

\begin{tabular}{clc}
\hline Learning Area & Sub Learning Area & Numbers \\
\hline & Natural numbers & 3 \\
& Operations with Natural Numbers & 12 \\
Numbers and & Fractions & 6 \\
Operations & Operations with Fractions & 2 nd \\
& Decimal Notation & 6 \\
& Percentages & 4 \\
\hline Geometry and & Basic Geometric Concepts and Drawings & 6 \\
Measurement & Triangles and Quadrilaterals & 4 \\
& Measuring Length and Time & 3 \\
& Measuring Area & 4 \\
\hline Data processing & Geometric Objects & 3 \\
\hline Total & Data Collection and Evaluation & 3 \\
\hline
\end{tabular}

Considering the distribution of objectives in the fifth grade mathematics curriculum, it is seen that the most objectives are in numbers and operations (33 objectives), then in geometry and measurement (20 objectives), and the least in data processing ( 3 objectives). By looking at the objectives, it is possible to predict which subject will be allocated more or less time during the period.

When we examine the achievements of the fifth grade mathematics teaching program within the framework of the competencies determined by the Ministry of National Education, the results in the graphic below are revealed.

Chart 1. Examination of the Competencies Targeted in Fifth Grade Mathematics Lesson Objectives within the Framework of the Competencies Defined by the Ministry of Education

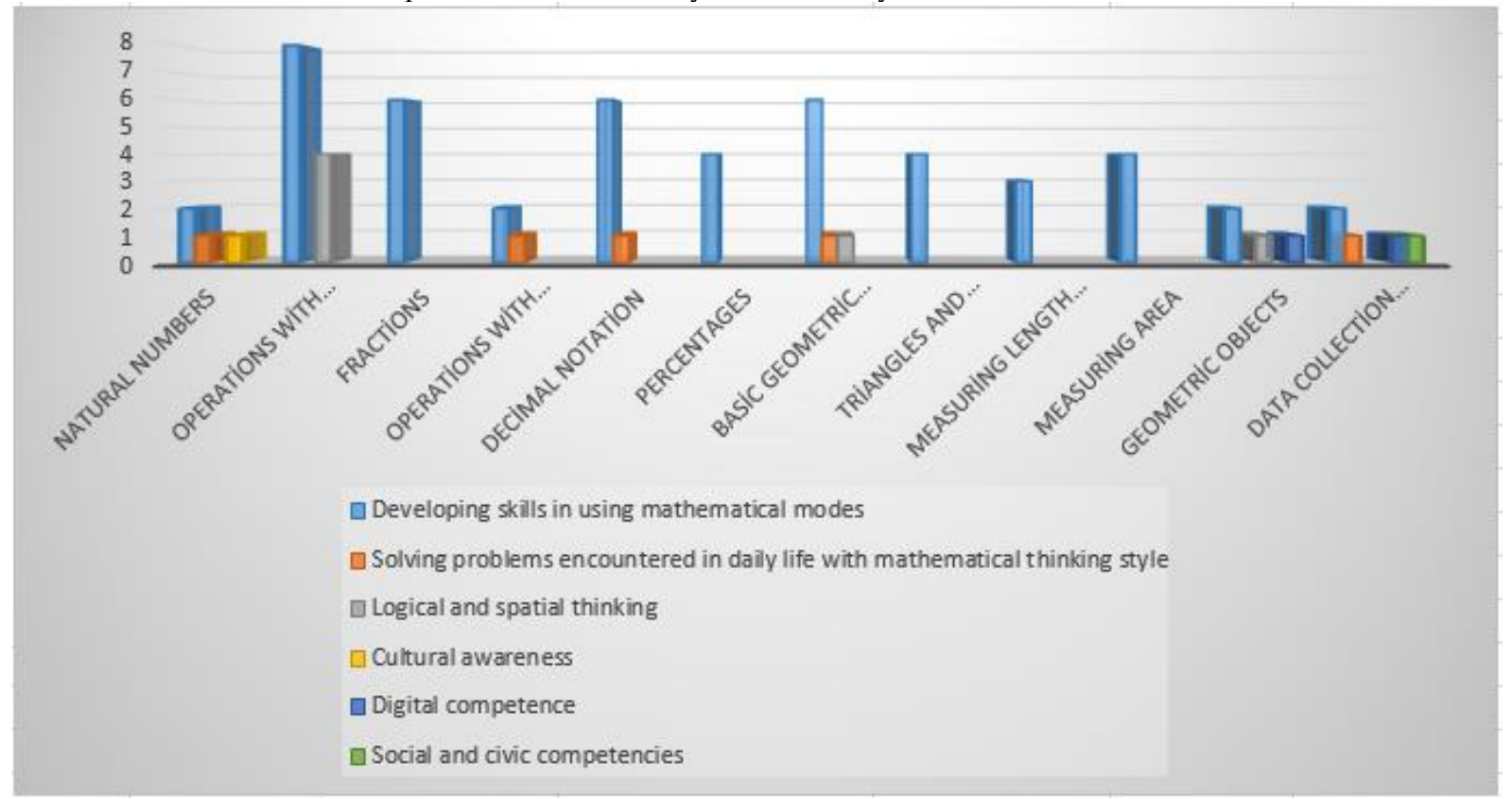

MEB has embedded eight competencies as 21st century skills into the curriculum. Among these competencies, "communication in mother tongue" and "communication in foreign languages" competencies were not sought, considering that they are not suitable for mathematics course objectives. It is seen that the achievements of the fifth grade mathematics curriculum are generally written to improve mathematics 
competence skills. Considering the sub-dimensions of the mathematics competence skill, it can be said that the objectives focus on the skill of "developing skills in using mathematical modes" and then trying to gain "logical and spatial thinking" and "solving problems encountered in daily life" skills. It was observed that "developing skills in using mathematical modes" passed in 49 out of 56 objectives, "logical and spatial thinking" skill passed in six objectives and "solving problems encountered in daily life" skill in five objectives. The skill of "logical and spatial thinking" is found in the objectives of "operations with natural numbers" (4 times). It has been observed that the "digital competence" skill has passed in two objectives, "cultural awareness" and the "social and civic competencies" skill in one objective. Fifth grade mathematics curriculum objectives do not include "learning to learn" and "taking initiative and entrepreneurship" skills.

In order to better reveal the relationship between objectives and 21st century skills, we can express which skills reflect through sample objectives as follows. In the objectives of "addition and subtraction with natural numbers up to five digits" in the unit of operations with natural numbers, it can be an example to gain the skill of "developing skills in using mathematical modes", which is the sub-dimension of the "mathematical competence" skill. As an example of "logical and spatial thinking" skill and "problem solving" skill, which is the sub-dimension of "mathematics competence" skill can be given, since it is possible to reach an information that is not given over the relationships by using the information given in the objective of "finds the elements (multiplier, quotient, or divisor) not given in operations by understanding the relationship between multiplication and division operations" in the operations unit with natural numbers. The objective of "Collecting data related to research questions and displaying it with frequency table and column chart. Appropriate information and communication technologies are used when necessary to organize and graphically display data." in the data collection and evaluation unit includes many skills. This objective can be an example of gaining "ICT literacy" skills as well as "developing skills in using mathematical modes" and "digital competence" skills.

Chart 2. Examination of the competencies targeted in fifth grade mathematics lesson objectives within the framework of Voogt and Roblin (2010) study.

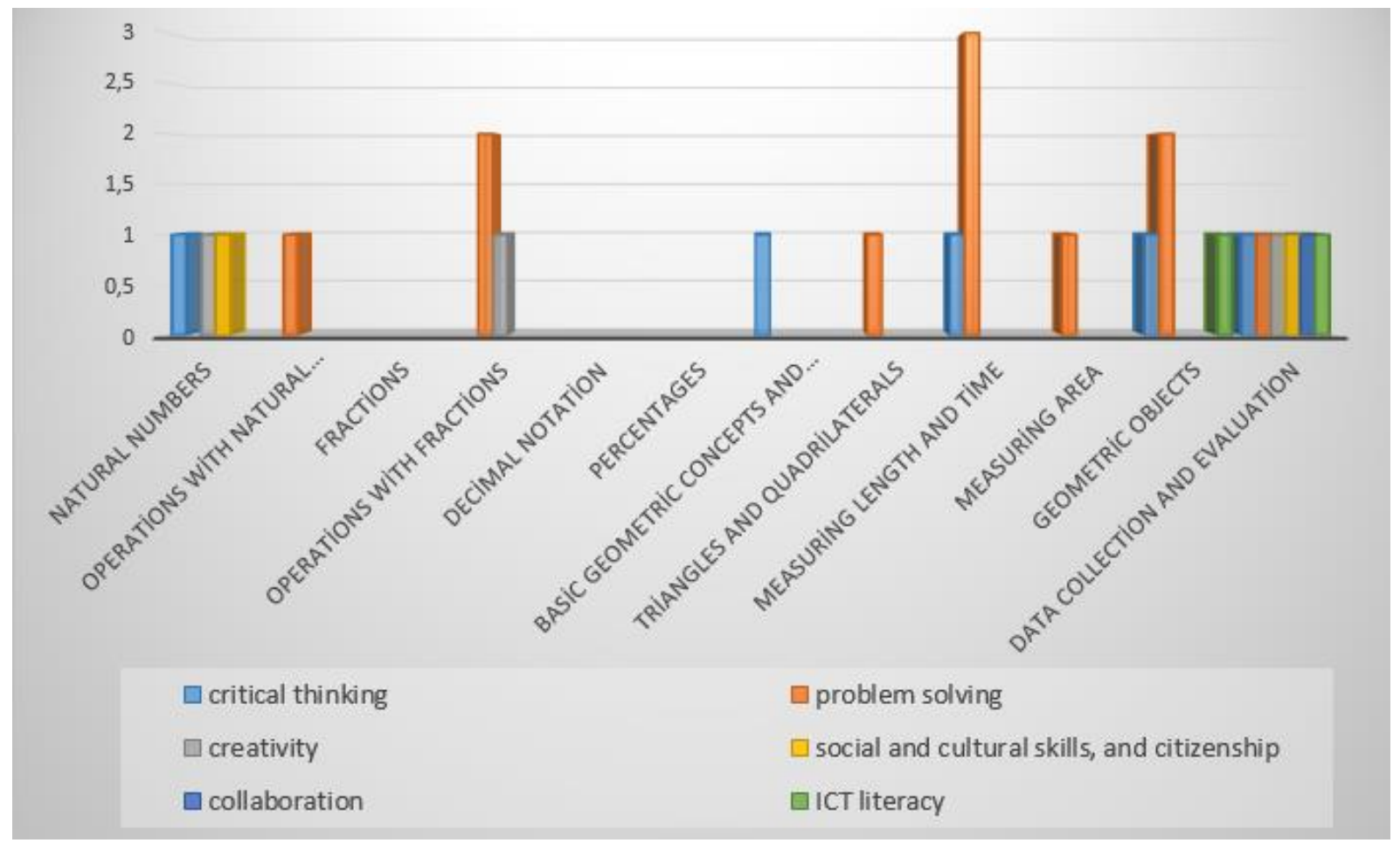

In the framework of the common skills that Voogt and Roblin (2010) revealed in their study, fifth grade Mathematics course objectives were examined. As a result of the analysis, it was not found any objectives related with "communication" and "productivity" skills. When the objectives were examined, "problem solving" skill eleven times, "critical thinking" skill five times, "creativity" skill three times, "ICT literacy" two times, "social and cultural skills and citizenship" skill two times, and "collaboration" skill once have been seen in the curriculum. 
Some objectives also involve more skills. If we give an example of objective involving more than one skill, the objectives in data collection and evaluation unit such as "a) While creating research questions that require data collection: In order to form a research question, examples 'What are the favorite fruits of students in a class are a research question, but the question of what a person's favorite fruit is not a research question.' $b$ ) While creating research questions, environmental awareness, frugality, helping each other, avoiding waste, etc. topics are included" include "solving problems encountered in daily life with mathematical thinking style", "social and civic competencies", "creativity", "collaboration" and "social and cultural skills and citizenship" skills. As the objective, "It specifies the parts and digits of up to nine-digit natural numbers, and the digit values of the numbers. In cases of associating these numbers with real life, studies for comparison and interpretation are included", can be given as an example to gain the skill of "critical thinking". In this objective, it requires critical thinking skill to associate, compare and interpret numbers with real life.

\section{RESULT, DISCUSSION, AND SUGGESTIONS}

Two different categories were used to examine fifth grade mathematics curriculum objectives in terms of gaining 21st century skills. The first category was determined as the skills that the MoNE aims to gain while developing the program. Within the framework of this category, the skills of "learning to learn", "taking initiative and entrepreneurship" in the mathematics curriculum are not included in the program's objectives. When the objectives are examined, "social and civic competencies" and "cultural awareness" pass once, and "digital competence" passes twice. These findings support the findings of Taşç1's (2004) study that 5th grade mathematics teachers found the changes insufficient in the mathematics curriculum and that changes should be made in the mathematics curriculum. When the objectives are examined in terms of the sub-dimensions of mathematics competence, "developing skills in using mathematical modes" is the most passing skill. The skills of "logical and spatial thinking" and "solving problems encountered in daily life with mathematical thinking style" are passed six and five times, respectively. Berkant and İncecik (2018), who conducted research on the 5th grade mathematics curriculum, stated in his study that the new curriculum was effective in the development of students' mathematical skills and that the objectives were easily understood.

The new educational programs aim to provide the student with knowledge for daily life by structuring. From this perspective, it is expected that "daily life" skills will be used more in the mathematics curriculum. Adding activities related to daily life to the content of the mathematics course will help to gain the skill of "solving problems encountered in daily life with mathematical thinking style".

We are in a period in which communication technologies have developed so much, that people have the opportunity to access information at any time. From this point of view, "learning to learn" is an important skill in terms of enabling individuals to learn on their own. When we look at the objectives, there is no information about the learning to learn skill. The objectives towards this skill should be included in the program. As a matter of fact, Goldsmith and Mark (1999) stated in their study that the mathematics curriculum should be oriented towards using educational technologies, individual learning with collaborative learning, mathematical thinking and discussion, understanding and solving problems correctly. Goldsmith and Mark realized the importance of learning to learn 20 years ago and, accordingly, stated that these concepts should be added to the mathematics curriculum of the concepts of individual learning, collaborative learning and educational technologies.

"Taking initiative and entrepreneurship" is one of the most important skills that employees of private companies or individual investors should have. Today, states support individuals as much as possible to establish their own companies and to make investments. The way to achieve this is to provide individuals with initiative and entrepreneurship skills. Taking initiative and entrepreneurship skills are skills that should be acquired by individuals in the long run. In order to gain this skill to students, it is necessary to do activities for this skill in more than one course. 5th grade mathematics lesson objectives remained missing to take initiative and develop entrepreneurship skills. In fact, the structure and content of the mathematics lesson are suitable for teaching these skills. Hereof, program developers need to develop the program in a more visionary and content-enriching way. This skill can be tried to be used in activities in mathematics lesson.

We can say that the most important feature of the information and communication age is visual software developed in every field. Nowadays, many new software useful in every field are developed and 
used. Many free and paid software for the field of mathematics have been developed and continue to be developed. Teachers can take advantage of these software in the lesson, both in a more enjoyable and effective way. In addition, the lessons will be more visible with this software.

The second category was determined as the common 21st century skills introduced by Voogt and Roblin (2010). Under this category, the "communication" and "productivity" skills of the mathematics curriculum are not included in the program's objectives. When the objectives are analyzed, it is seen that the "problem solving" skill eleven times, the "critical thinking" skill five times, the "creativity" skill three times, "social and cultural skills and citizenship" and "ICT literacy" skills twice, and the "collaboration" skill once was passed.

We can say that the "communication" skill, which was never mentioned in the objectives of the fifth grade mathematics curriculum, has two dimensions today. The first of these is the face-to-face communications and using body language which is called the classical type of communication. Classroom activities and group works are required to ensure this kind of communication. The second is the non-face-toface communication type that occurs with the development of communication devices, in a virtual environment. This type of communication takes place in many different ways. In the past, it was only in the form of voice transmission over the phone, but later it was started to be made by e-mail, but today it has become more complex in the form of both sound, image and written material transmission. Today we need to teach not only students but also teachers to use all kinds of different and complex communication methods.

In the fifth grade mathematics lesson objectives, there is no objective in the form of "productivity" skill that students can bring out. Changing the structure of the lesson in a way that will bring a product to the students during or at the end of the lesson, and the preparation of the curriculum will help students gain productivity skills.

In general, adding daily life activities and giving examples from daily life are effective in terms of gaining 21st century skills. In order to provide students with ICT literacy skills, activities requiring the use of technology can be added to the objectives. In addition, students can take individual responsibilities in their own learning can be easily added to mathematics lessons.

Defined as 21st century skills, which Voogt and Roblin (2010) defined as common skills, these skills are the qualities that international companies and firms want the personnel they will need for 20 years from now on. We can say that these skills do not find enough place in the objectives of fifth grade mathematics teaching programs. It is important for students to be educated that these skills are adequately included both in other courses and in mathematics lessons. In this respect, updating the objectives of the fifth grade mathematics curriculum in a way that will enable them to gain 21st century skills will enable the generations to be trained to look to the future with more hope. It will also allow future companies to find the personnel they will need.

\section{SUGGESTIONS}

Within the scope of this study, fifth grade mathematics teaching program objectives were examined within the scope of 21st century skills and interpreted accordingly. It is stated that some of the 21st century skills are not directly included in the program objectives but are implicitly taught by the teachers in the field of study through the auxiliary resources used in the course. Therefore, in order to ensure the reliability of the results obtained here, examining the auxiliary sources used in the course and making teacher interviews will make the results of the study more meaningful.

The following suggestions can be made to ensure that the objectives of the fifth grade mathematics curriculum to gain 21st century skills:

- In order to enable students to produce solutions for problems encountered in daily life, it is necessary to benefit more from daily life activities in lessons.

- If possible, more group work, research assignments and project assignments should be given to students to gain the ability to learn to learn. We need to include activities and studies that show students the ways to access information on their own. 
- Activities can be made for students in mathematics lessons. At these activities, students may be asked to establish companies or make private investments. In this way, students gain knowledge and skills for both real-life mathematical operations and entrepreneurship and taking initiative.

- Determining in advance which software can be used for the subjects in the mathematics lesson and teaching the lesson with this specified software will guide teachers in using software in the lesson.

- We need to improve students' face-to-face communication skills by doing group work and creating discussion environments in math class. In addition, after the lesson, activities can be defined in a way that enables students to use electronic media that allows the transfer of images and messages under the supervision of teachers in order to ensure that students continue to communicate with each other, and students can also learn and use these new communication technologies effectively.

- Mathematics lesson should be designed in a way that is based on practice and activity rather than abstract and rote-oriented, so students can do activities by using the information they have learned during the lesson and produce different products at the end of the lesson process. In order to design mathematics lesson in this way, it should be thought about how we can design the lessons for each subject based on practice and activity.

\section{REFERENCES}

Ananiadou, K., \& Claro, M. (2009). 21st century skills and competences for new millennium learners in OECD countries. OECD Education Working Papers, No. 41, OECD Publishing.

Berkant, H. G., \& İncecik, A. (2018). Ortaokul matematik dersi beşinci sınıf öğretim programının öğretmenlerin görüşlerine göre değerlendirilmesi. International Journal of Education Technology and Scientific Researches,3(6), 99-125.

Bloor, M., \& Wood, F. (2006). Keywords in qualitative methods: A vocabulary of research concepts. London: Sage Publications.

Bolat Soycan, S. (2006). 2005 yılı ilköğretim 5. sınıf matematik programının değerlendirilmesi. Yüksek Lisans Tezi, Uludağ Üniversitesi Eğitim Bilimleri Enstitüsü, Bursa.

Checkley, K. (2006). The essentials of mathematics K-6: Effective curriculum, instruction and assessment. Alexandria, VA: Association for Supervision and Curriculum Development.

Dede, C. (2010). Comparing frameworks for 21st century skills. In J. Bellanca, \& R. Brandt, $21^{\text {st }}$ century skills: Rethinking how students learn içinde (s. 51-76). Indiana: Solution Tree.

Ekici, G., Abide, Ö. F., Canbolat, Y., \& Öztürk, A. (2017). 21. yüzyıl becerilerine ait veri kaynaklarının analizi. Ĕ̆itim ve Öğretim Araştırmaları Dergisi, 6(1).

Framework for 21st Century Learning, http://www.battelleforkids.org/networks/p21/frameworks-resources, Erişim Tarihi: 25-06-2019

Goldsmith, T. L., \& Mark, J. (1999). What is a standarts-based mathematics curriculum. Educational Leadership, 57(3), 40-44.

İzci, E., \& Göktaş, Ö. (2014). Matematik öğretmenlerinin 5. sınıf matematik dersi öğretim programına ilişkin görüşleri. Dumlupınar Üniversitesi Sosyal Bilimler Dergisi, 41, 317-328.

Milli Eğitim Bakanlığı (MEB), 2018. Matematik dersi öğretim programı. Ankara

Organisation for Economic Co-operation and Development. (OECD). (2009). 21 st century skills and competences for new millennium learners in OECD countries. Education Working Papers, 41.

Peretz, D. (2006). Enhancing reasoning attitudes of prospective elementary school math ematics teachers. Journal of Mathematics Teacher Education, 9(4), 381-400.

Porter, A. (1989). A curriculum out of balance: The case of elementary school mathematics. Educational researcher, 18(5), 9-15. 
Rotherham, A. J., \& Willingham, D. (2009). 21st century skills: The challenges ahead. Educational Leadership, 67(1), 16-21.

Schleicher, A. (2012). Preparing teachers and developing school leaders for the 21st century: Lessons from around the world. OECD Publishing. 2, rue Andre Pascal, F-75775 Paris Cedex 16, France.

Silva, E. (2009). Measuring skills for 21st century learning. Phi Delta Kappa, 90(9), 630-634

Taşçı, Ö. (2004). İlköğretim II. kademe matematik programının değerlendirilmesi. Yüksek Lisans Tezi, Dokuz Eylül Üniversitesi Eğitim Bilimleri Enstitüsü, İzmir.

Voogt, J., \& Roblin, N. P. (2010). 21st century skills discussion paper. University of Twente.

Voogt, J., \& Roblin, N. P. (2012). A comparative analysis of international frameworks for 21st century competences: Implications for national curriculum policies. Journal of Curriculum Studies, 44(3), 299321. doi:10.1080/00220272.2012.668938

Yıldırım, A., \& Şimşek, H. (2011). Sosyal bilimlerde nitel araştırma yöntemleri. Ankara: Seçkin Yayıncilık. 